\title{
Prevalence of HBs Antigen, and HCV and HIV Antibodies in a Young Male Population in Cameroon
}

\author{
Dominique Noah Noah ${ }^{1,2 *}$, Firmin Ankouane Andoulo ${ }^{3,4}$, Brice Valery Moussima Essoh ${ }^{3}$, \\ Georges Nko'0 Ayissi' ${ }^{1}$, Servais Albert Fiacre Eloumou Bagnaka1,5, Magloire Biwole Sida ${ }^{3}$ \\ ${ }^{1}$ Faculty of Medicine and Pharmaceutical Sciences, University of Douala, Douala, Cameroon \\ ${ }^{2}$ Gastroenterology Service of the Yaounde Central Hospital, Yaounde, Cameroon \\ ${ }^{3}$ Faculty of Medicine and Biomedical Sciences, University of Yaounde 1, Yaounde, Cameroon \\ ${ }^{4}$ Hepatology and Gastroenterology Department, Yaounde University Teaching Hospital (CHU), Yaounde, \\ Cameroon \\ ${ }^{5}$ Douala General Hospital, Douala, Cameroon \\ Email: "noahnoahd@yahoo.fr
}

Received 15 October 2015; accepted 19 December 2015; published 22 December 2015

Copyright (C) 2015 by authors and Scientific Research Publishing Inc.

This work is licensed under the Creative Commons Attribution International License (CC BY).

http://creativecommons.org/licenses/by/4.0/

(c) (i) Open Access

\begin{abstract}
Introduction: According to WHO estimates, $57 \%$ of cases of liver cirrhosis and $78 \%$ of primary liver carcinoma are caused by a hepatitis B or C virus. This study aimed to assess the prevalence of these diseases and HIV among a young male population, according to region. Methods: This was a descriptive cross-sectional study conducted from 17 February to 31 March 2014 in the ten administrative regions of Cameroon. The study included male subjects of Cameroonian nationality aged at least 18 and at most 23 , and living in the regions concerned. It excluded subjects that did not match the age, gender, and nationality criteria. For each subject, $10 \mathrm{ml}$ of blood was collected in a dry tube. After centrifugation at 3000 RPM for 5 minutes, the serum was collected for the detection of viral infections. For subjects that tested positive, a confirmatory test was conducted. Results: In total, 4367 subjects were selected, with an average age of $20.46(+/-1.17)$ years. The prevalence of hepatitis B virus stood at $13.01 \%$ (with $95 \%$ CI: $12.03 \%-14.05 \%$ ). That of viral hepatitis $\mathrm{C}$ was $0.30 \%$ (95\% CI: $0.17 \%-0.52 \%)$. Co-infection with hepatitis B and $\mathrm{C}$ viruses was $0.05 \%$ (95\% CI: $0.01 \%-0.18 \%)$. The prevalence of HIV infection was $1.01 \%$ (95\% CI: $0.74 \%$ $1.36 \%)$. Conclusion: The overall prevalence of HBsAg in the population of young males is high. It tallies with the early vertical and horizontal modes of transmission that prevail in our environment.
\end{abstract}

\footnotetext{
${ }^{*}$ Corresponding author.
}

How to cite this paper: Noah, D.N., Andoulo, F.A., Essoh, B.V.M., Ayissi, G.N., Bagnaka, S.A.F.E. and Sida, M.B. (2015) Prevalence of HBs Antigen, and HCV and HIV Antibodies in a Young Male Population in Cameroon. Open Journal of Gastroenterology, 5, 185-190. http://dx.doi.org/10.4236/ojgas.2015.512028 


\section{Keywords}

\section{Hepatitis B Virus, Hepatitis C Virus, HIV Infection, Young Male Population, Cameroon}

\section{Introduction}

Chronic viral hepatitis is a global public health concern. In fact, two billion people worldwide are infected with hepatitis B virus, over 350 million suffer from chronic liver disease, including 60 million in Africa, and, every year, between 500,000 and 700,000 people die there from [1].

The World Health Organization (WHO) estimates that $57 \%$ of cases of liver cirrhosis and $78 \%$ of primary liver carcinomas result from a hepatitis B or C virus [1].

In Cameroon, according to a review of literature published between 1985 and 2014 concerning studies on sentinel populations (blood donors, pregnant women, health workers, Pygmies), prevalence ranges between $6.1 \%$ and $25.3 \%$ [2] [3] for hepatitis B virus (HBV), and $0.6 \%$ and $21 \%$ for hepatitis C virus (HCV) [4] [5].

There is little epidemiological data on the general population for HBV and HCV infections.

This study sought to determine the prevalence of these diseases and HIV in an apparently healthy male population aged 18 - 23 years in the 10 regions of Cameroon.

\section{Patients and Methods}

This was a descriptive cross-sectional study conducted from 17 February to 31 March 2014 in the ten (10) administrative regions of Cameroon. The study included male subjects of Cameroonian nationality aged at least 18 and at most 23, and living in the regions concerned. It excluded subjects that did not meet the age and residence criteria as well as those who were not of Cameroonian nationality. The subjects were selected among young volunteers in a screening survey as part of the implementation of a program to fight against viral hepatitis. Sampling was consequential. The study was conducted in the chief town of each administrative region of Cameroon. For each subject, $10 \mathrm{ml}$ of blood was collected in a dry tube. After centrifugation at 3000 RPM for 5 minutes, the serum was collected for the detection of viral infections. A rapid diagnostic test (TROD) (the One Step HBsAg rapid test of Inter China Chemical Ltd.) was performed for qualitative detection of HBsAg, and then an ELISA confirmatory test (ELISA HBsAg Kit of CTK Biotech, San Diego, California) was conducted for those that tested positive in the first assay. For HCV infection, a TROD (HCV cassette strip of Runbio Biotech Co. Ltd, Guangdong, China) was first performed, then an ELISA confirmatory test (HCV Ab ELISA kit of Runbio Biotech Co. Ltd, Guangdong, China) was conducted for those who tested positive in the first assay. For the human immunodeficiency virus (HIV), a test was performed to detect anti-HIV 1/2 Ab (Alere Determine TM HIV 1/2 of Orlando, Florida), then a second test (ELISA Genscreen TM ultra HIV Ag-Ab Bioo-Rad, Marnes-la-Coquette, France) was carried out to detect viral antigens in the sera of the subjects that tested positive in the first assay.

All the subjects screened were informed of the results by mail. Those who tested positive were referred to a gastroenterologist for follow-up. Those who tested negative were urged to get vaccinated against the hepatitis B virus and counselling sessions on the other viruses were organized in each region. The survey protocol was approved by the National Ethics Committee.

The data was keyed in and analysed using Epi Info 6.04 software and Excel 2007. As for the quantitative variables, averages and their standard deviations, as well as medians and their interquartile ranges (IQR), were calculated. The proportions of qualitative variables with their confidence intervals (CI) at $95 \%$ were determined.

To examine the relationship between two discrete variables, we used Pearson's chi-squared test $\left(\chi^{2}\right)$ and calculated the related risks, as well as Yates' correction and Fisher's exact test for small numbers, for a significance level set at $5 \%$.

\section{Results}

In total 4367 male subjects were selected, with an average age of $20.5+/-1.8$ years (Table 1 ). 
Table 1. Distribution of subjects according to region $(n=4367)$.

\begin{tabular}{cccc}
\hline Regions & Number of candidates & Percentage & $95 \%$ CI \\
\hline South West & 196 & $4.49 \%$ & {$[3.90 \% 5.16 \%]$} \\
North West & 349 & $7.99 \%$ & {$[7.21 \% 8.85 \%]$} \\
Adamawa & 400 & $9.16 \%$ & {$[8.33 \% 10.06 \%]$} \\
Littoral & 298 & $6.82 \%$ & {$[6.10 \% 7.62 \%]$} \\
Far North & 539 & $12.34 \%$ & {$[11.39 \% 13.36 \%]$} \\
Centre & 594 & $13.60 \%$ & {$[12.61 \% 14.66 \%]$} \\
North & 497 & $11.38 \%$ & {$[10.46 \% 12.37 \%]$} \\
West & 596 & $13.65 \%$ & {$[12.65 \% 14.71 \%]$} \\
East & 400 & $9.16 \%$ & {$[8.33 \% 10.06 \%]$} \\
South & 498 & $11.40 \%$ & {$[10.48 \% 12.39 \%]$} \\
\hline
\end{tabular}

The overall prevalence of HBsAg carriers was 13.01\% (95\% CI: $12.03 \%$ - 14.05\%). That of anti-HCV antibodies was $0.30 \%$ (95\% CI: $0.17 \%-0.52 \%)$.

The highest prevalence rate for HBV was recorded in the Far-North Region where $22.82 \%$ of the 539 subjects tested were infected, followed by the North region with 21.53\% $(n=497)$, the East with $14 \%(n=400)$, and the Adamawa with $12.75 \%(n=400)$. The region with the lowest prevalence rate is the South with $5.22 \%(n=498)$ $(\mathrm{p}<0.001)$.

As for HCV, the highest prevalence rates were recorded in the East, Adamawa, and North Regions with 1\% (n $=400), 0.75 \%(n=400)$, and $0.60 \%(n=497)$ respectively. The lowest prevalence rates recorded were in the South, West, Far-North, Littoral, and South-West Regions with $0 \%(p=0.0434)$.

The highest prevalence rate for HIV was recorded in the East Region, where $3.50 \%$ of subjects were infected $(n=400)$, as compared to $0.00 \%$ for the Littoral $(n=298)$ and North-West $(n=349)$ regions $(p<0.001)$ (Figure 1).

Co-infection with hepatitis B virus and hepatitis C virus was $0.05 \%$ (95\% CI: $0.01 \%-0.18 \%$ ). The prevalence of HIV infection was 1.01\% (95\% CI: 0.74\% - 1.36\%).

Figure 2 shows region-specific prevalence of HBV, HCV, and HIV infections in 10 regions of Cameroon.

\section{Discussion}

Most epidemiological studies conducted in Cameroon on the prevalence of viral hepatitis were carried out on target populations. This study stands out in that it was conducted at the national level on apparently healthy individuals in each of the country's 10 regions.

The overall prevalence of HBsAg in this study was $13.01 \%$. It fell within the wide range of prevalence rates recorded in a literature review of various studies conducted in Cameroon on target populations and ethnic groups between 1985 and 2014, with values ranging from $0.7 \%$ in a study conducted in 2013 by Rey Cuille et al., [6] within a population of primary school children in 2013 , to $25.3 \%$ in a study conducted in northern Cameroon by Garrigue et al., in 1985 [7]. A study conducted on blood donors at the University of Douala in 2009 by Mogtomo et al., found a HBsAg carrier prevalence ranging between 6.1 and 16\% [8]. Studies targeting pregnant women found prevalence rates ranging between 7.7\% and 20.4\% [9] [10]. A study conducted in 2013 by Ngo Sack et al. among children suffering from sickle cell anaemia at the Yaounde Central Hospital found a prevalence rate of 6.48\% [11]. In some ethnic groups, such as the Baka pygmies, the prevalence rates found ranged between $9.4 \%$ and $14.2 \%$ [12] [13]. However, these studies only targeted certain geographic regions and social groups. They were not representative of the general population. To the best of our knowledge, this study, although it focuses on young adult males only, is the first in Cameroon to describe a healthy population of individuals that comes close to the general population.

Anti-HCV antibodies were found in $0.3 \%$ of the subjects in our population, a prevalence rate which, accord- 


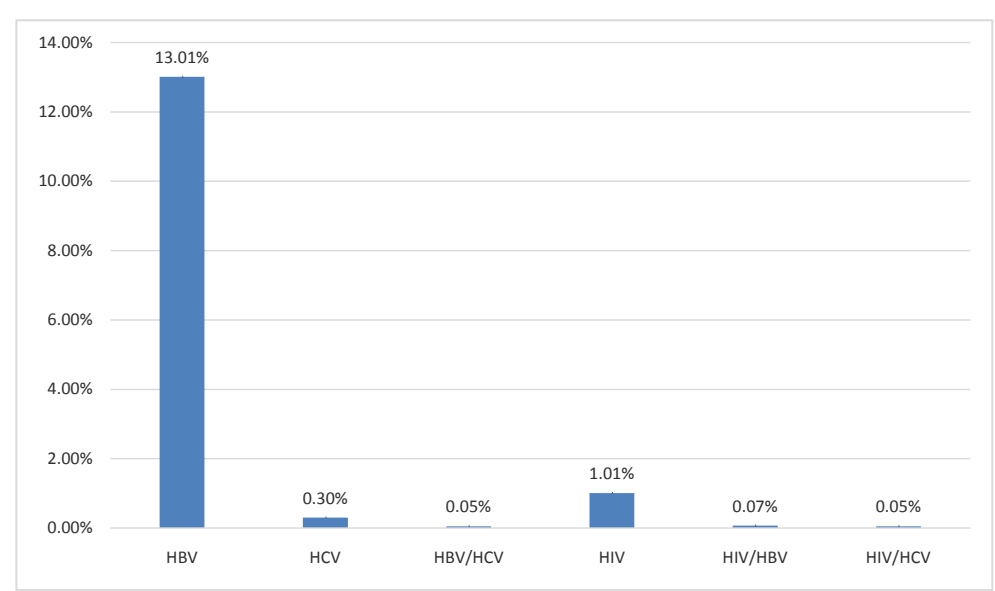

Figure 1. Prevalence of hepatitis B and C viruses, HIV, and co-infections.

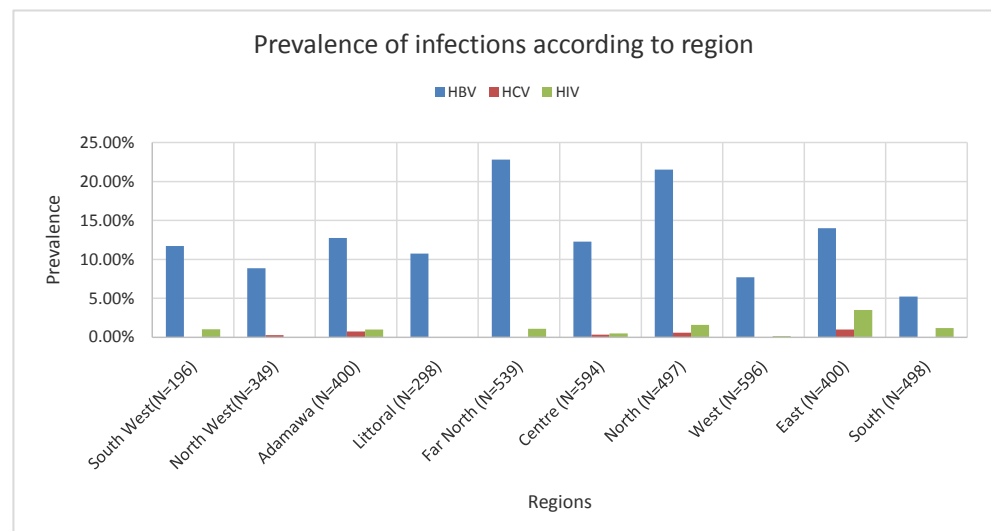

Figure 2. Geographical distribution of HBV, HCV and HIV infections in Cameroon.

ing to a review of literature published between 1992 and 2014 [14] [15], is lower than those found in most studies conducted on target populations in Cameroon. The said studies estimated the prevalence rates to be between $0.6 \%$ to $21 \%$. In Egypt, the prevalence rate varies between $5.9 \%$ and $26.5 \%$ [16]. The rate recorded in our study could be due to the age group chosen, that is males aged below 25. This result is similar to those obtained in 29 surveys in sub-Saharan Africa published by Madhava et al. in 2002 that showed that prevalence tended to increase with age. Thus, the specific median prevalence among subjects under 20 years was 1.3\% (22 studies, range: $0 \%-11 \%$ ), between 20 and 40 years was 3\% (29 studies, range: $0 \%-28 \%$ ), and among those over 40 years was $12 \%$ (29 studies, range: $0 \%-55 \%$ ) [17]. This increase in prevalence with age indicates that the risk of HCV transmission increases over time, and is strongly linked to the use of inadequately sterilized reusable equipment [16].

The rate of co-infection with HBV and HCV in our study population was $0.05 \%$, which is lower than the $0.21 \%$ reported by Fouelifack et al. in a study conducted in 2012 among blood donors at the Yaounde University Teaching Hospital, and close to the result obtained by Noubiap et al. (0.01\%) in 2013 among blood donors in Edea. It is also lower than that recorded in viral hepatitis treatment centres in France [14] [15] [17]. This result could be due to the fact that our sample population was relatively young.

In this study, prevalence of HBV infection per administrative region was highest in the Far North Region, followed by the North and East Regions with 22.82\%, 21.53\%, and 14\% respectively. These results differed from those obtained by Ducancelle et al. in 2013 in the North among pregnant women (20.4\%) and those obtained by Foupouapouognigni et al. in the East, in 2011, among the Baka and Bakola Pygmies (11.8\%). We recorded the lowest prevalence rate in the South Region, followed by the West with $5.22 \%$ and $7.72 \%$ respectively. 
These results were different from those obtained by Kurbanof et al. in 2005 in a population of pygmies and Bantu in the South (9.4\%) [9] [12] [14]. These differences are due to the age distribution in the samples, given that our study population was the youngest.

In this study, we found a significant difference in prevalence of HBV infection between regions, a difference which is due to the existence (in the North, Far North, and East Regions, as compared to the rest of the country) of risk factors outlined in the 2011 Demographic and Health and Multiple Indicator Survey (DHS-MICS). Such risk factors include: illiteracy, low level of exposure to the media, polygamy and multiple sex partners, ineffective use of condoms, lack of prenatal care, and the practice of some traditional rites and beliefs [16].

For HCV and HIV infections, the highest prevalence rates recorded in this study were in the East Region, followed by the Adamawa Region. This is due to population movements in these regions, which border countries at war.

\section{Conclusion}

The overall prevalence of HBsAg in the young male population is high. It tallies with the early vertical and horizontal modes of transmission that prevails in our environment. However, there are regional differences that are partly due to the intermixing of populations in the sub-region. There is need to develop national hepatitis B and C control strategies through the Extended Programme on Immunization and make antiviral and antiretroviral therapies available.

\section{Participation of the Authors}

Dominique Noah Noah: design, drafting, and monitoring;

Firmin Ankouane Andoulo: literature review;

Brice Valery Moussima Essoh: Recruitment of test subjects and monitoring of work in the laboratory;

Goeges Nko'Ayissi: statistical analysis;

Servais Albert Fiacre Eloumou Bagnaka: literature review and proofreading;

Magloire Biwole Sida: general supervision.

\section{References}

[1] Matthews, P.C., Geretti, A.M., Goulder, P.J. and Klenerman, P. (2014) Epidemiology and Impact of HIV Coinfection with Hepatitis B and Hepatitis C Viruses in Sub-Saharan Africa. Journal of Clinical Virology, 61, 20-33. http://dx.doi.org/10.1016/j.jcv.2014.05.018

[2] Koanga Mogtomo, M.L., Louandji Fomekong, S., Fotso Kuate, H. and Ngono Ngane, A. (2009) Détection des agents infectieux dans les banques de sang de Douala [Detection of Infectious Agents in Blood Banks in Douala] (1995-2004). Cahiers d'études et de recherches francophones/Santé, 19, 3-8.

[3] Garrigue, G., Merlin, M., Durand, J.P., Josse, R., Kollo, B., Trepo, C. and Bemba, D.K. (1985) Prevalence of Markers of Viral Hepatitis B in Northern Cameroon. Bull Soc Pathol Exot Filiales, 78, 883-889.

[4] Foupouapouognigni, Y., Sadeuh Mba, S.A., Betsem à Betsem, E., Rousset, D., Froment, A., Gessain, A., et al. (2011) Hepatitis B and C Virus Infections in the Three Pygmy Groups in Cameroon. Journal of Clinical Microbiology, 49, 737-740. http://dx.doi.org/10.1128/JCM.01475-10

[5] Laurent, C., Bourgeois, A., Mpoudi, M., Butel, C., Mpoudi-Ngolé, E. and Delaporte, E. (2007) HIV and Hepatitis C Virus Coinfection, Cameroon. Emerging Infectious Disease, 13, 514-516. http://dx.doi.org/10.3201/eid1303.061069

[6] Rey-Cuille, M.A., Njouom, R., Bekondi, C., Seck, A., Gody, C., Bata, P., et al. (2013) Hepatitis B Virus Exposure during Childhood in Cameroon, Central African Republic and Senegal after the Integration of HBV Vaccine in the Expanded Program on Immunization. The Pediatric Infectious Disease Journal, 32, 1110-1115. http://dx.doi.org/10.1097/INF.0b013e31829be401

[7] Ducancelle, A., Abgueguen, P., Birguel, J., Mansour, W., Pivert, A., Le Guillou-Guillemette, H., et al. (2013) High Endemicity and Low Molecular Diversity of Hepatitis B Virus Infections in Pregnant Women in a Rural District of North Cameroon. PLoS One, 8, e80346. http://dx.doi.org/10.1371/journal.pone.0080346

[8] Fomulu, N.J., Morfaw, F.L.I., Torimiro, J.N., Nana, P., Mve Koh, V. and Takang, W. (2013) Prevalence, Correlates and Pattern of Hepatitis B among Antenatal Clinic Attenders in Yaounde-Cameroon: Is Perinatal Transmission of HBV Neglected in Cameroon? BMC Pregnancy Childbirth, 13, 158. http://dx.doi.org/10.1186/1471-2393-13-158

[9] Ngo Sack, F., Noah Noah, D., Zouhaïratou, H. and Mbanya, D. (2013) Portage de l'antigène HBs et des anticorps antiVHC chez le drépanocytaire homozygote à l’Hôpital Central de Yaoundé [HBsAg and Anti-HCV Antibody Carrier 
Rates Among Homozygous Sickle Cell Patients at the Yaounde Central Hospital]. The Pan African Medical Journal, 14, 40. http://dx.doi.org/10.11604/pamj.2013.14.40.2069

[10] Kurbanov, F., Tanaka, Y., Fujiwara, K., Sugauchi, F., Mbanya, D., Zekeng, L., et al. (2005) A New Subtype (Subgenotype) Ac (A3) of Hepatitis B Virus and Recombination between Genotypes A and E in Cameroon. Journal of General Virology, 86, 2047-2056. http://dx.doi.org/10.1099/vir.0.80922-0

[11] Ndumbe, P.M., Atchou, G., Biwole, M., Lobe, V. and Ayuk-Takem, J. (1993) Infections among Pygmies in the Eastern Province of Cameroon. Medical Microbiology and Immunology, 182, 281-284. http://dx.doi.org/10.1007/BF00191943

[12] Desenclos, J.C. (2003) L’infection par le virus de l’hépatite C dans le monde: Importance en santé publique, modes de transmission et perspectives [Hepatitis C Virus Infection in the World: Importance in Public Health Care, Modes of Transmission, and Prospects.]. Virologie, 7, 177-191.

[13] Madhava, V., Burgess, C. and Drucker, E. (2002) Epidemiology of Chronic Hepatitis C Virus Infection in Sub-Saharan Africa. The Lancet Infectious Diseases, 2, 293-302. http://dx.doi.org/10.1016/S1473-3099(02)00264-5

[14] Noubiap, J.J.N., Joko, W.Y.A., Nansseu, J.R.N., Tene, U.G. and Siaka, C. (2013) Sero-Epidemiology of Human Immunodeficiency Virus, Hepatitis B and C Viruses, and Syphilis Infections among First-Time Blood Donors in Edea, Cameroon. International Journal of Infectious Diseases, 17, e832-e837. http://dx.doi.org/10.1016/j.ijid.2012.12.007

[15] Fouelifack Ymele, F., Keugoung, B., Fouedjio, J.H., Kouam, N., Mendibi, S. and Dongtsa Mabou, J. (2012) High Rates of Hepatitis B and C and HIV Infections among Blood Donors in Cameroon: A Proposed Blood Screening Algorithm for Blood Donors in Resource-Limited Settings. Journal of Blood Transfusion, 2012, Article ID: 458372. http://dx.doi.org/10.1155/2012/458372

[16] Fritzsche, C., Becker, F., Hemmer, C.J., Riebold, D., Klammt, S., Hufert, F., Akam, W., Kinge, T.N. and Reisinger, E.C. (2013) Hepatitis B and C: Neglected Diseases among Health Care Workers in Cameroon. Transactions of the Royal Society of Tropical Medicine and Hygiene, 107, 158-164. http://dx.doi.org/10.1093/trstmh/trs087

[17] Dhumeaux, D. (2014) Prise en Charge des personnes infectées par les virus de l'hépatite B ou de l’hépatite C [Management of Persons Infected with Hepatitis B or Hepatitis C Virus]. 2014 Report under the Supervision of the ANRS and AFEF 2014, 1-18. 